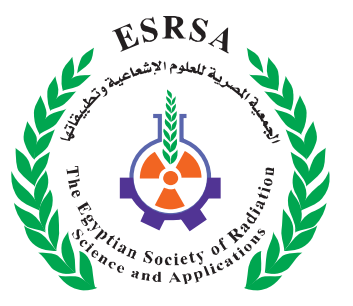

J. Nucl. Tech. Appl. Sci., Vol. 6, No. 1, PP. 31 : 45 (2018)

\title{
Effect of Heat Stress on Reproductive and Productive Traits in Baladi and Crossbred Goat Does under Subtropical Conditions
}

\author{
El-Sayed A.I.M. ${ }^{1}$, Farghaly H.A.M. ${ }^{2}$, Eid S.Y. ${ }^{2}$ and El-Zaher H.M. ${ }^{2}$
}

Received: 14/01/2018

Accepted: 13/02/2018

E.mail:hus_ahm2002@yahoo.com

\section{KEYWORDS}

Heat Stress, Reproductive and Productive Traits, Crossing, Female Goats, Cortisol.

\section{ABSTRACT}

This experiment was conducted to study the effect of heat stress on some reproductive and productive performance in purebred and crossbred female goats under both of hot (summer season) and mild climatic (winter season) conditions. Forty mature female goats (20 Baladi and 20 crossbred (50\% Zaraibi x 50\% Baladi) used in this research. Results showed fertility rate, conception rate, kidding rate, prolificacy and fecundity were higher in experimental does during mild climate conditions than hot climate conditions. Birth weight recorded higher values in mild climate conditions in comparison with hot climate conditions. Concerning to breed, reproductive traits were higher in crossbred goat does compared with purebred goat does. Crossbred goat does showed higher $(\mathrm{P}<0.01$ or $\mathrm{P}<0.0001)$ in all productive traits than Baladi goat does. Cortisol hormone concentration showed lower $(\mathrm{P}<0.0001)$ concentration under mild climate conditions than hot climate conditions during different stages of estrous cycle, pregnancy and postpartum periods. On the other hand cortisol concentration showed low significant variations $(\mathrm{P}<0.0001)$ in crossbred goat does compared with purebred does during different stages of estrous cycle, except diestrous period. Similar trend was found during pregnancy and postpartum periods $(\mathrm{P}<0.01$ or $\mathrm{P}<0.0001)$. It could be concluded that each of season and breed have a significant effect on reproductive and productive traits of goats and in the same time, crossbred was better than purebred goats.

1. Department of Animal Production, Faculty of Agriculture, Benha University, Benha, Egypt, P.O.13736.

2. Department of Biological Applications, Radioisotopes Applications Division, Nuclear Research Center, Atomic Energy Authority, Inshas, Cairo, Egypt, P.O.13759. 


\section{INTRODUCTION}

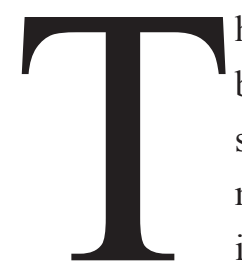

he summer in Egypt, is characterized by high ambient temperature, intense solar radiation and high relative humidity. Therefore, farm animals raised in such sever climatic stress for almost 6 months of the year and become uncomfortable and they suffer extremely in production, reproduction and resistance to diseases and parasites (Marai et al., 2002). Heat stress has a reducing effect on both the productivity and reproductive efficiency of farm animals (Jordan, 2003). The deleterious effects of heat stress are the result of either the hyperthermia associated with heat stress or the physiological adjustments made by the heat-stressed animal to regulate body temperature (Hansen, 2009). As well as, cortisol, secreted by the adrenal glands, stimulates physiological changes, which allow the animal a better tolerance to the stress caused by high temperature (Christison and Johnson, 1972).

Cortisol hormone also plays a very important role in many physiological functions, especially energy production, thermal regulation, lactogenesis, and regulation of milk production (Abdel Samee $\boldsymbol{e t}$ al., 2000). High productive imported animals can be crossed with selected high productive native animals because such practice may raise the productivity of the heat tolerant native animals (Marai and Habeeb, 2010). A properly designed crossbreeding system allows the livestock producer to take advantage of appropriate combinations of the superior traits of several different breeds and it also yields heterosis which often referred to as hybrid vigor, measures the difference between average performance of crossbred animals and average performance of the breeds that were crossed to produce them (Olson, 2011).

The main objective of this study is to examine the effect of heat stress on some reproductive and productive traits during hot climate conditions com- pared with mild climate conditions in each of native Baladi as purebred goat does and in its crosses with Zaraibi as crossbred goat does (50\% Zaraibi x $50 \%$ Baladi) to evaluate adaptability of two breeds, point out hot climate conditions condition of Egyptian environment.

\section{MATERIALS AND METHODS}

\section{Experimental animals:}

Forty native female goats, 20 Baladi and 20 crossbred goat does (50\% Zaraibi x 50\% Baladi) were used. The does were selected according to reproductive farm records and subjected to the study. Their age ranged from 2 to 3 years old and the mean body weight for Baladi and crossbred was ranging from $25 \pm 1.5 \mathrm{~kg}$ to $35 \pm 1.6 \mathrm{~kg}$, respectively. All animals were healthy and clinically free of diseases.

\section{Animal housing:}

All experimental goats were kept in semi-open pens throughout the period of experiment. These pens provided enough shade and ventilation in summer and protection from rain in winter. The does were allowed to graze five hours daily at least.

\section{Animal feeding:}

The experiment was carried out in the Experimental Farms Project (Goats Farm), Nuclear Research Center, Atomic Energy Authority, Inshas. The experimental goats were fed basal ration of concentrate feed mixture (CFM) according to the allowances of NRC (2007) of goats. The CFM composed of $37.4 \%$ wheat bran, $27 \%$ yellow corn, $12.5 \%$ soybean meal, $10.0 \%$ undecorticated cottonseed cake, $5 \%$ rice bran, $4 \%$ sugarcane molasses, $3 \%$ limestone, $1 \%$ sodium chloride and 0.1 vitamin and minerals premix. Concentrate feed mixture was offered once daily at $10 \mathrm{am}, 3.5 \%$ of body weight. Barseem hay was offered ad libitum. Fresh drinking water was available at all time. 


\section{Experimental procedure:}

The does selected were estrus synchronized and divided into two groups (20 does per group) per each climate conditions. All animals received intramuscularly (IM) injection of $10 \mathrm{ml}$ of prostaglandin F2 $\alpha$ (PGF2 $\alpha$ ) (lutalyse) in double dose ( $5 \mathrm{mg} /$ dose) 11 days interval because of immaturity of follicles. After 24 hours of the second injection the does received 500 I.U of hCG IM as ovulation induction. After hCG injection two fertile buck (one buck for each group) introduced to the does in each group Baladi does and crossbred does in terms of Baladi and crossbred buck, respectively and allowed to be with them for two successive estrous cycles for estrous detection and natural mating.

\section{Ambient temperature, relative humidity and temperature humidity index:}

The ambient temperature and relative humidity were obtained daily from meteorological station of Atomic Energy Authority during the whole experimental period. The temperature humidity index (THI) was calculated during mild (period from October, 2013 to March, 2014) and hot (period from May, 2014 to October, 2014) climate conditions according to Marai et al. (2000) as: $\mathrm{THI}=\mathrm{db}{ }^{\circ} \mathrm{C}-[(0.31$ $\left.0.31 \mathrm{RH}) \times\left(\mathrm{db}^{\circ} \mathrm{C}-14.4\right)\right]$, where, $\mathrm{THI}=$ temperature humidity index, $\mathrm{db}{ }^{\circ} \mathrm{C}=$ dry bulb temperature in Celsius and $\mathrm{RH}=$ relative humidity $\%$ (Table 1$)$.

A value for THI $<22.2$ was considered remarkably an absence of heat stress, while the values 22.2 to 23.3 referred to moderate (mild) heat stress, 23.3 to $<25.6$ referred to severe heat stress and $>25.6$ referred to very severe heat stress. The estimated THI values were 22.17 and 31.43 during mild and hot climate conditions, respectively, showed that absence of heat stress (A value for THI < 22.2) during mild climate conditions and exposure of the experimental animals to very severe heat stress (A value for THI > 25.6) during hot climate conditions.

Table (1): Averages of ambient temperature $\left(A T,{ }^{\circ} \mathrm{C}\right)$, relative humidity $(R H \%)$ and temperature humidity index (THI) values at mid-day during the experimental periods.

\begin{tabular}{|c|c|c|c|c|}
\hline Climate & $\begin{array}{l}\text { Experimental } \\
\text { months }\end{array}$ & $\begin{array}{c}\text { Ambient } \\
\text { temperature, }{ }^{\circ} \mathrm{C}\end{array}$ & $\begin{array}{c}\text { Relative } \\
\text { Humidity, \% }\end{array}$ & $\begin{array}{c}\text { Temperature } \\
\text { Humidity index (THI) }\end{array}$ \\
\hline \multirow{7}{*}{ 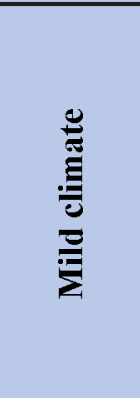 } & October & $27.61 \pm 0.39$ & $79.19 \pm 1.75$ & 26.76 \\
\hline & November & $25.57 \pm 0.49$ & $83.00 \pm 3.34$ & 24.98 \\
\hline & December & $18.87 \pm 0.80$ & $75.87 \pm 2.81$ & 18.54 \\
\hline & January & $19.84 \pm 0.40$ & $80.65 \pm 2.49$ & 19.51 \\
\hline & February & $20.50 \pm 0.54$ & $86.96 \pm 2.21$ & 20.25 \\
\hline & March & $23.90 \pm 0.63$ & $77.06 \pm 2.97$ & 23.22 \\
\hline & Overall & $22.68 \pm 0.33$ & $80.27 \pm 1.10$ & $\begin{array}{c}22.17 \\
\text { (Absence of heat stress) }\end{array}$ \\
\hline \multirow{7}{*}{ 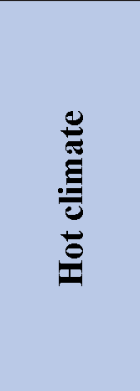 } & May & $31.29 \pm 0.74$ & $70.68 \pm 3.09$ & 29.75 \\
\hline & June & $33.90 \pm 0.63$ & $72.83 \pm 2.03$ & 32.26 \\
\hline & July & $34.19 \pm 0.33$ & $82.42 \pm 1.23$ & 33.11 \\
\hline & August & $35.06 \pm 0.29$ & $82.45 \pm 1.21$ & 33.94 \\
\hline & September & $33.43 \pm 0.49$ & $73.93 \pm 0.93$ & 31.80 \\
\hline & October & $28.94 \pm 0.38$ & $74.45 \pm 2.33$ & 27.79 \\
\hline & Overall & $32.79 \pm 0.26$ & $76.16 \pm 0.86$ & $\begin{array}{c}31.43 \\
\text { (Very severe heat stress) }\end{array}$ \\
\hline
\end{tabular}

Each value of air temperature or relative humidity was the average of estimates recorded each day weekly at $12.00 \mathrm{pm}$. 


\section{Blood sampling:}

Blood samples were collected directly from the jugular vein in evacuated glass tubes. Puncture of jugular vein was carried out using vacutainer needle (Becton and Dickinson N. J. 07070 U.S.A). Collected blood samples were kept at room temperature from 30 to $60 \mathrm{~min}$ for clotting, and then centrifuged at $3000 \mathrm{rpm}$ for $15 \mathrm{~min}$. to separate serum. After that, serum was stored at $-20^{\circ} \mathrm{C}$ until analysis. Samples were collected throughout the different stages of estrous cycle (estrus, metestrus, diestrus and proestrus). Consequently blood sample were monthly withdrawn during pregnancy period. After parturition (postpartum) it was collected at the time of parturition then every 15 -day up to 30 days of postpartum.

\section{Hormonal assay:}

Cortisol were analyzed by radioimmunoassay technique (RIA) using Coat-A-count I125 RIA kits (lot No. 140524C), purchased from IZOTOP, Institute of isotopes Ltd., Budapest, Hungary.

\section{Measurements of reproductive traits}

The following reproductive traits were estimated on the does according to Charring et al. (1992): Fertility $=$ No. of goats kidded/ No. of goats joined to the buck x 100. Prolificacy (litter size) $=$ No. of kids born/ No. of goats kidded. Fecundity $=$ No. of kids born/ No. of goats joined to the buck x 100 . Kidding rate $=$ No. of goats kidded/ No. of pregnant goats $\times 100$. Conception rate $=$ No. of pregnant goats (aborted or delivered) / No. of goats joined to the buck x 100 .

\section{Statistical analysis}

Data were expressed as least square means \pm SE. Covariance analysis was carried out due to the significant differences found in the metabolic weight (initial live body weights ${ }^{0.75}$ ) of the experimental goat does (Atta, 2014). Data were statistically analyzed using procedure of SAS (1991) according the following model: $\mathbf{Y}_{\mathrm{ijk}}=\boldsymbol{\mu}+\mathbf{S}_{\mathrm{i}}+\mathbf{B}_{\mathrm{j}}+\mathbf{S B}_{\mathrm{ij}}+\mathbf{b}(\mathbf{X}-\overline{\mathbf{x}})+$ $\mathbf{e}_{\mathrm{ijk}}$ where: $\mu=$ the overall mean; $S_{j}=$ the fixed effect of season of the year $(1=$ mild and $2=$ hot $) ; B_{i}=$ the fixed effect of breed type $(1=$ crossbred and $2=$ purebred); $\mathrm{BS}_{\mathrm{ij}}=$ the interaction between the breed type and season of the year; $b=$ regression coefficient of $\mathrm{Y}$ on metabolic weight; $\overline{\mathrm{x}}=$ the arithmetic mean of metabolic weight; $\mathrm{e}_{\mathrm{ij \textrm {j }}}=$ random error. Significance of the difference in the results was verified by Duncan's new multiple ranges test (Duncan, 1955).

\section{RESULTS}

\section{Effect of heat stress conditions, breed and their interaction on reproductive traits}

Data presented in Table 2 show that fertility rate does recorded $40 \%$ and $75 \%$ during hot and mild climate conditions, respectively. In addition, crossbred does recorded $80 \%$ higher than Baladi (70\%) during mild climate conditions, however recorded $50 \%$ and $30 \%$, respectively during hot climate conditions. Conception rate was higher in experimental does during mild climate conditions $(92.5 \%)$ than hot climate conditions $(67.5 \%)$ (Table 2).

Crossbred does recorded $100 \%$ and Baladi does recorded $85 \%$ during mild climate conditions, while it recorded $75 \%$ and $60 \%$, respectively during hot climate conditions. Kidding rate was higher in experimental does during mild climate conditions (81.11\%) than hot climate conditions (59.26\%).

Crossbred does recorded $80 \%$ and Baladi does recorded $82.35 \%$ during mild climate conditions, while it recorded $66.67 \%$ and $50 \%$, respectively during hot climate conditions. Prolificacy was slightly higher in experimental does during mild climate conditions (1.67) than hot climate conditions (1.63). Crossbred does recorded 1.88 and Baladi does recorded 1.43 during mild climate conditions, while it recorded 1.8 and 1.33 , respectively during hot climate conditions. Fecundity was slightly higher in 
experimental does during mild climate conditions (125\%) than hot climate conditions (65\%). Crossbred does recorded $150 \%$ and Baladi does recorded $100 \%$ during mild climate conditions, while it recorded $90 \%$ and $40 \%$, respectively during hot climate conditions.
Data obtained from breed effect on reproductive traits revealed that crossbred does (Zaraibi x Baladi) showed higher reproductive traits in terms of conception rate, kidding rate fertility rate, prolificacy and fecundity as compared with purebred (Baladi does).

Table (2) : Effect of season and breed on doe's reproductive traits.

\begin{tabular}{|c|c|c|c|c|c|c|c|c|c|}
\hline Item & $\begin{array}{c}\text { No. } \\
\text { does }\end{array}$ & $\begin{array}{c}\text { Pregnant } \\
\text { No. }\end{array}$ & $\begin{array}{c}\text { Kidded } \\
\text { No. }\end{array}$ & $\begin{array}{c}\text { kids } \\
\text { No. }\end{array}$ & $\begin{array}{c}\text { Fertility } \\
\text { rate\% }\end{array}$ & $\begin{array}{c}\text { Conception } \\
\text { rate \% }\end{array}$ & $\begin{array}{c}\text { kidding } \\
\text { rate\% }\end{array}$ & Prolificacy & $\begin{array}{c}\text { Fecundity } \\
\%\end{array}$ \\
\hline $\begin{array}{c}\text { Mild } \\
\text { climate }\end{array}$ & 40 & 37 & 30 & 50 & 75 & 92.5 & 81.11 & 1.67 & 125 \\
\hline Purebred & 20 & 17 & 14 & 20 & 70 & 85 & 82.35 & 1.43 & 100 \\
\hline Crossbred & 20 & 20 & 16 & 30 & 80 & 100 & 80 & 1.88 & 150 \\
\hline $\begin{array}{c}\text { Hot } \\
\text { climate }\end{array}$ & 40 & 27 & 16 & 26 & 40 & 67.5 & 59.26 & 1.63 & 65 \\
\hline Purebred & 20 & 12 & 6 & 8 & 30 & 60 & 50 & 1.33 & 40 \\
\hline crossbred & 20 & 15 & 10 & 18 & 50 & 75 & 66.67 & 1.80 & 90 \\
\hline Chi Sq. & & & & & 0.08 & 0.02 & 0.08 & 0.29 & 0.29 \\
\hline P-value & & & & & 0.78 & 0.89 & 0.78 & 0.59 & 0.59 \\
\hline
\end{tabular}

Effect of heat stress conditions, breed and their interaction on productive traits

Table 3 showed that analysis of covariance revealed significant effect $(\mathrm{P}<0.01)$ for season change on birth weight and birth weight of mild climate conditions was higher about $0.68 \mathrm{Kg}$ than hot climate conditions with change rate $-22.01 \%$ in hot climate conditions. In addition, season had insignificantly effect on litter size (change rate $-2.4 \%$ in hot climate conditions) and weaning weight (change rate $-7.5 \%$ in hot climate conditions), while breed effect showed highly significant $(\mathrm{P}<0.0001)$ effect on weaning weight, also $(\mathrm{P}<0.01)$ on litter size and birth weight. Interaction revealed insignificantly effect on litter size, birth weight and weaning weight. Litter size of crossbred does was higher about 0.44 more than Baladi does with change rate $-18.5 \%$ and $+22.6 \%$ in Baladi and crossbred, respectively (Table $3)$. Birth weight of crossbred does was higher about $0.53 \mathrm{Kg}$ than Baladi does with change rate $-18.5 \%$ and $+22.6 \%$ in Baladi and crossbred does, respec- tively (Table 3). Weaning weight of crossbred does was higher about $2.02 \mathrm{Kg}$ than Baladi does with change rate $-30.2 \%$ and $+43.3 \%$ in Baladi and crossbred does, respectively (Table 3 ).

\section{Effect of heat stress conditions, breed and their interaction on cortisol concentration}

\section{During estrous cycle period:}

Cortisol concentrations increased in does under hot climate conditions during estrous cycle, it recorded highest cortisol concentration during estrus phase $(25.25 \pm 2.49 \mathrm{ng} / \mathrm{mL})$, and lowest cortisol concentration at metestrus phase $(20.55 \pm 1.40 \mathrm{ng} / \mathrm{mL})$ (Table 4). Similar trend of increase, but with lower rate was found in does under mild climate conditions, it recorded highest cortisol concentration during estrus phase $(15.82 \pm 0.32 \mathrm{ng} / \mathrm{mL})$, and lowest cortisol concentration at proestrus and metestrus phases $12.24 \pm 0.25$ and $12.38 \pm 0.71 \mathrm{ng} / \mathrm{mL}$, respectively. On the other side, Baladi does recorded higher cortisol concentration than crossbred does in both hot and mild climate conditions 
during estrous cycle phases. In addition, change rate was $-33.5 \%,-31.5 \%,-14.9 \%$ and $-33.4 \%$ during estrus, metestrus, diestrus and proestrus, respectively in crossbred does (Table 4). Obtained results revealed that there was a significant variation in all estimations of estrous cycle phases in cortisol concentrations $(\mathrm{P}<0.0001)$ due to season and breed, except insignificant variations during diestrus phase due to breed effect. Also, it was found significant $(\mathrm{P}<0.0001)$ variation in cortisol concentrations due to interaction between season and breed in proestrus and estrus phases, also $(\mathrm{P}<0.05)$ during diestrus phase and insignificant variations during metestrus phase (Table 4).

Table (3) : Effect of heat stress conditions and breeds on litter size, birth and weaning weight (Kg) of kids under experimental conditions.

\begin{tabular}{|c|c|c|c|}
\hline Item & Litter size & Birth weight (Kg) & Weaning weight (Kg) \\
\hline \multicolumn{4}{|c|}{ Season (S) } \\
\hline Mild climate & $1.67 \pm 0.09$ & $3.09^{\mathrm{A}} \pm 0.18$ & $6.04 \pm 0.35$ \\
\hline Hot climate & $1.63 \pm 0.13$ & $2.41^{\mathrm{B}} \pm 0.12$ & $5.59 \pm 0.38$ \\
\hline Change (\%) & -2.4 & -22.01 & -7.5 \\
\hline$P$-value & $0.5438^{\mathrm{NS}}$ & $0.0008^{* *}$ & $0.3780^{\mathrm{NS}}$ \\
\hline \multicolumn{4}{|c|}{ Breed (B) } \\
\hline Purebred & $1.4^{\mathrm{B}} \pm 0.11$ & $2.34^{\mathrm{B}} \pm 0.13$ & $4.66^{\mathrm{B}} \pm 0.32$ \\
\hline Crossbred & $1.84^{\mathrm{A}} \pm 0.07$ & $2.87^{\mathrm{A}} \pm 0.15$ & $6.68^{\mathrm{A}} \pm 0.29$ \\
\hline Change (\%) & +31.4 & +22.6 & +43.3 \\
\hline$P$-value & $0.0021^{* *}$ & $0.0015^{* *}$ & $0.0001^{* * *}$ \\
\hline \multicolumn{4}{|c|}{ Interaction $(\mathrm{S} * \mathrm{~B})$} \\
\hline \multicolumn{4}{|c|}{ Mild climate } \\
\hline Purebred & $1.43 \pm 0.14$ & $2.60 \pm 0.16$ & $5.08 \pm 0.46$ \\
\hline Crossbred & $1.88 \pm 0.09$ & $3.48 \pm 0.23$ & $6.84 \pm 0.44$ \\
\hline Change (\%) & +31.5 & +33.8 & +34.6 \\
\hline \multicolumn{4}{|c|}{ Hot climate } \\
\hline Purebred & $1.3 \pm 0.21$ & $2.16 \pm 0.18$ & $4.03 \pm 0.32$ \\
\hline Crossbred & $1.8 \pm 0.13$ & $2.57 \pm 0.15$ & $6.61 \pm 0.19$ \\
\hline Change (\%) & +38.5 & +18.9 & +64.02 \\
\hline$P$-value & 0.9423 NS & $0.2193 \mathrm{NS}$ & $0.1747^{\mathrm{NS}}$ \\
\hline
\end{tabular}

Means with different letters ( $A$ and $B)$ in the same column are significantly different at $(P<0.05)$.

$* *=P<0.01, * * * P<0.0001$ and $\mathrm{NS}=$ not significant. 
Table (4) : Effect of heat stress conditions and breeds on cortisol concentration in goat does during estrous cycle phases.

\begin{tabular}{|c|c|c|c|c|}
\hline \multirow{2}{*}{ Items } & \multicolumn{4}{|c|}{ Cortisol concentration during estrous cycle phases } \\
\hline & Estrus & Metestrus & Diestrus & Proestrus \\
\hline \multicolumn{5}{|c|}{ Season (S) } \\
\hline Mild climate & $15.82^{\mathrm{B}} \pm 0.32$ & $12.38^{\mathrm{B}} \pm 0.71$ & $15.40^{\mathrm{B}} \pm 0.56$ & $12.24^{\mathrm{B}} \pm 0.25$ \\
\hline Hot climate & $25.25^{\mathrm{A}} \pm 2.49$ & $20.55^{\mathrm{A}} \pm 1.40$ & $25.23^{\mathrm{A}} \pm 1.17$ & $22.02^{\mathrm{A}} \pm 2.01$ \\
\hline Change (\%) & +59.6 & +65.9 & +63.8 & +79.9 \\
\hline$P$-value & $0.0001^{* * *}$ & $0.0001^{* * *}$ & $0.0001^{* * *}$ & $0.0001^{* * *}$ \\
\hline \multicolumn{5}{|c|}{ Breed (B) } \\
\hline Purebred & $24.67^{\mathrm{A}} \pm 2.68$ & $19.54^{\mathrm{A}} \pm 1.52$ & $21.96^{\mathrm{A}} \pm 1.99$ & $20.56^{\mathrm{A}} \pm 2.46$ \\
\hline Crossbred & $16.40^{\mathrm{B}} \pm 0.35$ & $13.38^{\mathrm{B}} \pm 1.20$ & $18.67^{\mathrm{B}} \pm 1.27$ & $13.69^{\mathrm{B}} \pm 0.52$ \\
\hline Change (\%) & -33.5 & -31.5 & -14.9 & -33.4 \\
\hline$P$-value & $0.0001^{* * *}$ & $0.0001^{* * *}$ & $0.0674^{\mathrm{NS}}$ & $0.0001^{* * *}$ \\
\hline \multicolumn{5}{|c|}{ Interaction $(\mathrm{S} * \mathrm{~B})$} \\
\hline \multicolumn{5}{|c|}{ Mild climate } \\
\hline Purebred & $15.97^{\mathrm{b}} \pm 0.61$ & $14.63 \pm 0.42$ & $15.77^{\mathrm{c}} \pm 0.89$ & $12.46^{\mathrm{c}} \pm 0.47$ \\
\hline Crossbred & $15.66^{\mathrm{b}} \pm 0.26$ & $10.13 \pm 0.18$ & $15.03^{c} \pm 0.72$ & $12.02^{\mathrm{c}} \pm 0.17$ \\
\hline Change (\%) & -1.9 & -30.8 & -4.7 & -3.5 \\
\hline \multicolumn{5}{|c|}{ Hot climate } \\
\hline Purebred & $33.37^{\mathrm{a}} \pm 0.93$ & $24.46 \pm 0.63$ & $28.16^{\mathrm{a}} \pm 1.13$ & $28.67^{a} \pm 0.41$ \\
\hline Crossbred & $17.14^{\mathrm{b}} \pm 0.50$ & $16.64 \pm 1.46$ & $22.3^{\mathrm{b}} \pm 1.16$ & $15.38^{\mathrm{b}} \pm 0.19$ \\
\hline Change (\%) & -48.6 & -31.9 & -20.8 & -46.4 \\
\hline$P$-value & $0.0001^{* * *}$ & $0.0805^{\mathrm{NS}}$ & $0.0231^{*}$ & $0.0001^{* * *}$ \\
\hline
\end{tabular}

Least square means with different letters ( $A$ and $B$ or $a, b$ and $c)$ in the same column are significantly different at $(P<0.05)$. $*=P<0.05, * * * P<0.0001$ and $N S=$ not significant.

\section{During pregnancy period:}

Cortisol concentrations were significantly $(\mathrm{P}<0.0001)$ higher in hot climate conditions than in mild climate conditions during pregnancy periods with change rate $+23.6 \%,+51.02 \%$ and $+45.7 \%$ during early, mid and late pregnancy, respectively in hot climate conditions. It can be seen from Table 5 that cortisol concentrations were higher in hot climate conditions than in mild climate conditions during pregnancy periods reach peak value during late pregnancy $39.83 \pm 3.09 \mathrm{ng} / \mathrm{mL}$ in hot climate conditions and $27.33 \pm 1.99 \mathrm{ng} / \mathrm{mL}$ in mild climate conditions. However it recorded lower cortisol concentration during early pregnancy with value about $26.57 \pm 2.21 \mathrm{ng} /$ $\mathrm{mL}$ in hot climate conditions and $21.5 \pm 1.05 \mathrm{ng} / \mathrm{mL}$ in mild climate conditions. Baladi does recorded higher $(\mathrm{P}<0.0001)$ cortisol concentrations than crossbred does with change rate $-34.9 \%,-36.7 \%$ and $-38.9 \%$ during early, mid and late pregnancy, respectively On the other hand, cortisol concentrations were significantly higher in Baladi than in crossbred does at day of parturition $(\mathrm{P}<0.0001)$ and 15 days postpartum $(\mathrm{P}<0.01)$ 
and were not significantly different at 30 days postpartum. Also, cortisol concentration was higher in Baladi than in crossbred does during postpartum periods it recorded $42.16 \pm 2.41,23.64 \pm 0.45$ and $15.43 \pm 0.54 \mathrm{ng} /$ $\mathrm{mL}$ at day of parturition, 15 days postpartum and 30 days postpartum, respectively in Baladi does, while it recorded $25.98 \pm 1.59,20.64 \pm 0.21$ and $14.89 \pm 0.45 \mathrm{ng} /$ $\mathrm{mL}$ at day of parturition, 15 days postpartum and 30 days postpartum, respectively in crossbred does. In addition, the interaction effect between breed and season on cortisol concentration showed significantly affect
$(\mathrm{P}<0.01)$ at day of parturition. The interaction effect between season and breed on cortisol concentration showed significantly affect $(\mathrm{P}<0.0001)$ during early and late pregnancy.

\section{During postpartum period:}

From data obtained in Table 6 the cortisol concentrations were significantly higher $(\mathrm{P}<0.0001)$ in hot climate conditions than in mild climate conditions at day of parturition, 30 days postpartum and $(\mathrm{P}<0.01)$ at 15 days postpartum of the study.

Table (5) : Least square means ( $\pm S E)$ for factors affecting cortisol concentration in goat does during preg nancy period.

\begin{tabular}{|c|c|c|c|}
\hline \multirow[t]{2}{*}{ Items } & \multicolumn{3}{|c|}{ Cortisol concentration during pregnancy period } \\
\hline & Early & Mid & Late \\
\hline \multicolumn{4}{|c|}{ Season (S) } \\
\hline Mild climate & $21.5^{\mathrm{B}} \pm 1.05$ & $22.03^{\mathrm{B}} \pm 1.74$ & $27.33^{\mathrm{B}} \pm 1.99$ \\
\hline Hot climate & $26.57^{\mathrm{A}} \pm 2.21$ & $33.27^{\mathrm{A}} \pm 2.17$ & $39.83^{\mathrm{A}} \pm 3.09$ \\
\hline Change (\%) & +23.6 & +51.02 & +45.7 \\
\hline$P$-value & $0.0001^{* * *}$ & $0.0001^{* * *}$ & $0.0001^{* * *}$ \\
\hline \multicolumn{4}{|c|}{ Breed (B) } \\
\hline Baladi (Purebred) & $29.13^{\mathrm{A}} \pm 1.54$ & $33.87^{\mathrm{A}} \pm 1.88$ & $41.7^{\mathrm{A}} \pm 2.54$ \\
\hline Crossbred & $18.94^{\mathrm{B}} \pm 0.28$ & $21.43^{\mathrm{B}} \pm 1.71$ & $25.46^{\mathrm{B}} \pm 1.49$ \\
\hline Change (\%) & -34.9 & -36.7 & -38.9 \\
\hline$P$-value & $0.0001^{* * *}$ & $0.0001^{* * *}$ & $0.0001^{* * *}$ \\
\hline \multicolumn{4}{|c|}{ Interaction $(\mathrm{S} * \mathrm{~B})$} \\
\hline \multicolumn{4}{|c|}{ Mild climate } \\
\hline Baladi (Purebred) & $24.56^{\mathrm{b}} \pm 0.97$ & $27.67 \pm 0.38$ & $33.54^{b} \pm 0.23$ \\
\hline Crossbred & $18.45^{\mathrm{c}} \pm 0.45$ & $16.4 \pm 0.67$ & $21.12^{\mathrm{d}} \pm 1.41$ \\
\hline Change (\%) & -24.9 & -40.7 & -37.03 \\
\hline \multicolumn{4}{|c|}{ Hot climate } \\
\hline Baladi (Purebred) & $33.7^{\mathrm{a}} \pm 1.08$ & $40.08 \pm 0.18$ & $49.86^{\mathrm{a}} \pm 1.32$ \\
\hline Crossbred & $19.44^{\mathrm{c}} \pm 0.22$ & $26.47 \pm 1.51$ & $29.81^{\mathrm{c}} \pm 0.42$ \\
\hline Change (\%) & -42.3 & -33.9 & -40.2 \\
\hline$P$-value & $0.0001^{* * *}$ & $0.2060^{\mathrm{NS}}$ & $0.0013^{* *}$ \\
\hline
\end{tabular}

Least square means with different letters ( $A$ and $B$ or $a, b, c$ and $d)$ in the same column are significantly different at $(P<0.05)$. $* *=P<0.01,{ }^{* * *} P<0.0001$ and $N S=$ not significant. 
Table (6) : Least square means ( \pm SE) for factors affecting cortisol concentration in goat does during post partum period.

\begin{tabular}{|c|c|c|c|}
\hline \multirow{2}{*}{ Items } & \multicolumn{3}{|c|}{ Cortisol concentrations during postpartum period } \\
\hline & Day of parturition & 15 days Postpartum & 30 days Postpartum \\
\hline \multicolumn{4}{|c|}{ Season $(\mathbf{S})$} \\
\hline Mild climate & $28.25^{\mathrm{B}} \pm 1.93$ & $21.46^{\mathrm{B}} \pm 0.51$ & $13.88^{\mathrm{B}} \pm 0.33$ \\
\hline Hot climate & $39.9^{\mathrm{A}} \pm 3.21$ & $22.82^{\mathrm{A}} \pm 0.56$ & $16.44^{\mathrm{A}} \pm 0.32$ \\
\hline Change (\%) & +41.2 & +6.3 & +18.4 \\
\hline$P$-value & $0.0001^{* * *}$ & $0.0087^{* *}$ & $0.0001^{* * *}$ \\
\hline \multicolumn{4}{|c|}{ Breed (B) } \\
\hline Baladi (Purebred) & $42.16^{\mathrm{A}} \pm 2.41$ & $23.64^{\mathrm{A}} \pm 0.45$ & $15.43 \pm 0.54$ \\
\hline Crossbred & $25.98^{\mathrm{B}} \pm 1.59$ & $20.64^{\mathrm{B}} \pm 0.21$ & $14.89 \pm 0.45$ \\
\hline Change (\%) & -38.4 & -12.7 & -3.5 \\
\hline$P$-value & $0.0001^{* * *}$ & $0.0016^{* *}$ & $0.6605^{\mathrm{NS}}$ \\
\hline \multicolumn{4}{|c|}{ Interaction $(S * B)$} \\
\hline \multicolumn{4}{|c|}{ Mild climate } \\
\hline Baladi (Purebred) & $34.36^{\mathrm{b}} \pm 1.03$ & $22.74 \pm 0.64$ & $13.96 \pm 0.61$ \\
\hline Crossbred & $22.14^{\mathrm{d}} \pm 0.66$ & $20.18 \pm 0.29$ & $13.81 \pm 0.30$ \\
\hline Change (\%) & -35.6 & -11.3 & -1.07 \\
\hline \multicolumn{4}{|c|}{ Hot climate } \\
\hline Baladi (Purebred) & $49.96^{\mathrm{a}} \pm 0.25$ & $24.54 \pm 0.39$ & $16.89 \pm 0.19$ \\
\hline Crossbred & $29.83^{\mathrm{c}} \pm 2.19$ & $21.1 \pm 0.17$ & $15.98 \pm 0.56$ \\
\hline Change (\%) & -40.3 & -14.02 & -5.4 \\
\hline$P$-value & $0.0052^{* *}$ & $0.2987^{\mathrm{NS}}$ & $0.3127^{\mathrm{NS}}$ \\
\hline
\end{tabular}

Least square means with different letters ( $A$ and $B$ or $a, b, c$ and $d)$ in the same column are significantly different at $(P<0.05)$. $* *=P<0.01,{ }^{* * *} P<0.0001$ and $N S=$ not significant.

\section{DISCUSSION}

\section{Effect of heat stress conditions, breed on reproductive traits:}

The present results obtained from the season effect on fertility rate go in agreement with those of Fatet et al. (2011) who reported that in temperate regions, reproduction in goats is described as seasonal with breeding period in the fall and winter and important differences in seasonality between breeds and locations. In tropical regions, goats are consid- ered continuous breeders; however, restricted food availability often causes prolonged anestrous and an ovulatory periods and reduced fertility and prolificacy. In addition, Aboul-Naga and Aboul-Ela (1987); Abdel- Hafez (2002) and Marai et al. (2004) found that in ossimi and Rahmani sub-tropical sheep breeds and their crosses (Suffolk x Ossimi crossbred and different crosses between Finn) showed lower fertility and prolificacy in May (spring) than during September (autumn) and January (winter) matings under Egyptian conditions, due to the functional problems 
that occur in males and females at mating during periods of thermal stress (Curtis, 1983).

Obtained results for season effect on conception rate go in agreement with those stated that the summer mating season showed, in general, the lowest conception rate (Marai et al., 2006). In addition, Aboul- Naga and Aboul-Ela (1987) and Marai et al. (2004) found negative relationships between conception rate and ambient temperature and daylight length, in Ossimi, Rahmani and Ossimi x Suffolk ewes, respectively. Kinne (2000), reporting on Pigmy does in USA that does have lower conception rates in spring and summer when both photoperiod and temperature are rising, and that temperature over $32^{\circ} \mathrm{C}$ may cause thermal stress especially when combined with high humidity On the contrary, other studies showed that conception rate was the lowest for ewes mated either during the winter (El-Fouly et al., 1984) or during February and June mating seasons (Mokhtar et al., 1991).

Obtained results for season effect on kidding rate, prolificacy and fecundity go in agreement with those of Aboul-Naga and Aboul-Ela (1987) who found that litter size at birth / ewe mated was higher in autumn than in the other mating seasons. The september mating surpassed the may mating season by 36 and $29 \%$ in Rahmani and Ossimi, respectively. Moreover, Gabr et al. (1989) reported that ovulation rate and litter size were significantly higher in September (autumn) than in January (winter) and May (spring) breeding seasons in local Rahmani and Ossimi ewes. On the other hand, Abdel-Hafez (2002) and Marai et al. (2004 and 2006) found that the kidding rate insignificantly affected by breeding season of the year (summer, autumn and winter) in Ossimi $x$ Suffolk ewes, under sub-tropical conditions.

\section{Effect of heat stress conditions and breeds on productive traits}

Results obtained for effect of season on litter size go in agreement with those of Abdel-Hafez (2002) and Marai et al. (2004 and 2006) who found that the lambing rate insignificantly affected by breeding season of the year (summer, autumn and winter) in Ossimi x Suffolk ewes, under sub-tropical conditions. Steine (1975) found a significantly higher litter-number in winter than in summer in Norway. Also, Mellado and Meza-Herrera (2002) concluded that increment in litter size is expected with lower temperatures before or after hot days at time of mating. In addition, Madibela et al. (2002) and Dadi $\boldsymbol{e t}$ al. (2008) reported that the season of birth significantly affected litter size.

Results obtained for effect of season on birth weight go in agreement with those of Singh (1997) who observed significant effect of season of birth on body weights at 3 and 6 month of age. In addition, important influence of the season on kid live weights have been reported in several breeds (Warmington and Kirton, 1990 and Hermiz et al., 1997). Also, Taiwo et al. (2005) and Zahradden et al. (2008) reported a significant effect of season on birth weight of goat's kids. Mia et al. (2013) found that winter born kids of black Bengal goats were significantly $(\mathrm{P}<0.05)$ heavier at birth to 9 month of age, than their counterparts from the rainy season. The effect of the season may be explained partly by the climatic conditions, however, the feeding practices at different seasons for dams and offspring were similar. An important influence of the season on kid live weights have been reported in several breeds (Warmington and Kirton, 1990 and Hermiz et al., 1997). On the contrary, Singh et al. (1991), Husain et al. (1996) and Singh and Singh (1998) reported non-significant effect of the season of birth on body weights at different stages of growth. In addition, Abiola and Onwuka (1998) reported no significant effect of season on birth weight of West African Dwarf sheep and goats. Also, Al-Shorepy et al. (2002) observed non-significant effect of the season of birth on birth weight in Emirati goat.

Results obtained for effect of season on wean- 
ing weight go in agreement with those of Basu and Rao (1979) found no significant effect of season of birth on daily body weight gain from birth to weaning time. The lowest daily body weight gain value between birth and weaning was in summer-born goats. Al-Shorepy et al. (2002) observed a significant effect of season of birth on weaning weight in Emirati goat. Anous and Mourad (1993) reported that crossing of Alpines with Rove does produced rapidly growing weaned kids.

Results obtained for effect of breed on birth weight, weaning weight and litter size go in agreement with Brown and Machen, (1997) who reported that birth weight and weaning weight were improved in crossing Spanish, Nubian, or Angora with Boer goats. Abd-Allah et al. (2015) reported that Boer $\times$ Spanish crossbred goat kids had a higher pre-weaning daily gain than pure Spanish goat kids. In addition, Schoeman (2000) reported that Dorper crossbreds sheep showed superiority in reproductively and growth traits which were an advantage for improving productivity of animals.

\section{Effect of heat stress conditions and breeds on cortisol concentration}

On the other side, Obtained results for season effect on cortisol concentrations in does during estrous cycle, pregnancy and postpartum periods are in agreement with those of Habeeb et al. (2014) who found that cortisol was significantly $(\mathrm{P}<0.001)$ higher during summer by 31.7 than those in winter $25.0 \%$ in purebred and crossbred calves, respectively. Also, Habeeb et al. (2011) and (Marai and Habeeb, 1998) stated that the increase in cortisol concentration during acute heat stress may be attributed to the fact that the glucocorticoid hormones have hyperglycaemic action to increase gluconeogenesis and provide the expected increase in glucose utilization in heat stressed animals. In addition, the increase in cortisol concentration, as a catabolic hormone, in the heat stressed animals may be also due to the effect of stressful conditions on adrenal gland (Kamal and Johnson, 1971). These results are in agreement with Zhengkang et al. (1994) who recorded significant $(\mathrm{P}<0.01)$ increase in blood cortisol concentrations because of the increase of the environmental temperature. Moreover, plasma cortisol concentration was increased when animal was exposed to direct sunlight in hot summer (Mormède et al., 2011). According to Wise et al. (1988), plasma cortisol concentrations were higher in heat-stressed animals. These results are disagree with those obtained by Nazifi et al. (2003) who found that there were no significant differences in the concentration of cortisol at either heat stress or cold stress.

Result obtained revealed that cortisol concentrations were higher in Baladi than in crossbred does during estrous cycle, pregnancy and postpartum periods that lead to conclude that Zaraibi crossed with Baladi breed in the subtropical conditions perform better than the purebred local breed (Baladi does) and were also resistant to heat stress of summer season in Egypt. These results are in agreement with Habbeb et al. (2014) who reported that, crossbred calves were less affected by climatic condition in cortisol than purebred calves.

The increase in cortisol concentration during estrous phase goes in harmony with Kumar et al. (1991) and Madan et al. (1993) who all found that serum cortisol concentrations have been reported to be high on the day of estrus. These high concentrations may be due to stress caused by increased physical activity and also due to stress of estrus. In addition, serum concentration of cortisol was higher $(\mathrm{P}<$ $0.0002)$ in summer season $(26.29 \pm 1.04 \mathrm{ng} / \mathrm{mL})$ than in winter season $(20.27 \pm 1.15 \mathrm{ng} / \mathrm{mL}$ ) (Al-Samawi $\boldsymbol{e t}$ al., 2014). Moreover, the increase in cortisol concentration during late pregnancy is in agreement with Hennessy et al. (1982) who reported that during late pregnancy the maternal cortisol concentrations increased due to placenta transfer from the fetus to the mother. In addition, Suganaya and Gomathy (2009) found that cortisol started to increase 15 days 
prior to kidding and reach a maximum on the day of kidding, this increase is attributed to stress - induced by the fetus in initiating parturition (Ninan and Vadodaria, 2000).

In conclusion, it can be concluded that heat stress conditions of summer season (hot climate conditions) in Egypt had adversely effects on both reproductive and productive traits of both crossbred and Baladi goat does. In addition, crossbred goat does were better than purebred goat does in both reproductive and productive traits. Finally, this study revealed that crossed zaraibi with Baladi goat does (crossbreeding) perform better and were more adapted to the subtropical conditions of Egypt in comparison with the purebred Baladi goat does, it showed improvement in reproductive and productive traits especially under hot climate conditions.

\section{REFERENCES}

- Abd-Allah. S; Salama, R.; Mohamed, M. I.; Mabrouk, M. M.; EL-Kady, R. I.; Kadry A. I. and Sawsan. M. A. (2015). A comparative study on reproductive and productive performance of Boer and Baladi goats raised under similar environmental conditions in Egypt. International J. Chem. Tech. Res., 8 (9): 225-236.

- Abdel-Hafez, M.A.M. (2002). Studies on reproductive performance in sheep. Ph.D. Thesis, Faculty of Agriculture, Zagazig Univ., Zagazig, Egypt.

- Abdel-Samee, A.M., Kotby, E.A.; Mousa, M.R. and Abou-Fandoud, E.I. (2000). Plasma cortisol concentration in lactating Friesian as influenced by heat stress and some means of alleviation. Proceedings of the Conference of Social and Agricultural Development of Sinai, Al-Arish, North Sinai, Egypt. pp. 7-21.

- Aboul-Naga, A.M. and Aboul-Ela, M.B. (1987). Performance of sub-tropical Egyptian sheep breeds, European breeds and their crosses. 1. Egyptian sheep breeds. World Review of Anim. Prod., 23: 75-82.

- Abiola, S.S. and Onwuka, C.F.I. (1998). Reproductive performance of West African Dwarf sheep and goats at village level, Ogun State, Nigeria. Nig. J. Anim. Prod. 25 (1): 79 - 82.

- Al-Samawi, K.A.; Al-Hassan, M.J. and Swelum, A.A.(2014). Thermoregulation of female aardi goats exposed to environmental heat stress in Saudi Arabia. Indian J. Anim. Res., 48 (4): 344 - 349.

- Al-Shorepy, S, A.; Alhadrami, G. A. and Abdulwahab, K. (2002). Genetic and phenotypic parameters for early growth traits in Emirati goat. Small Rumin. Res. 453: 217-223 CAB Abst. 20023141182.

- Anous, M.R. and Mourad, M.M. (1993). Crossbreeding effects on reproductive traits of does and growth and carcass traits of kids. Small Rum. Res., 12(2):141149.

- Atta, M.A.A. (2014). Estimating the adaptability of bovine calves to hot climatic conditions. Ph.D. Thesis, Fac. Agric., Zagazig Univ., Egypt.

- Basu, S.B. and Rao, M.K. (1979). Growth pattern in Murrah buffalo calves. India. Vet. J., 56: 570-574.

- Brown, R. J. and Machen, R. (1997). Performance of meat goat kids sired by Boer bucks. Texas Agricultural Extension Service.

- Charring, J.; Humbert, J. M. and Levis, J., (1992): Manual of sheep production in the humid tropics of africa .C.A.B. International, pp.144.

- Christison G.I., Johnson H.D. (1972). Cortisol turnover in heat stressed cows. J. Anim. Sci., 53: 10051010 .

- Curtis, S.E. (1983). Environmental Management in Animal Agriculture. Iowa State University Press, Ames,USA.

- Dadi, H.; Duguma, G.; Shelima, B.; Fayera, T.; Tadesse, M.; Woldu, T. and Tucho, T.A. (2008). Nongenetic factors influencing post-weaning growth and reproductive performances of Arsi-Bale goats. Livestock Research for RuralDevelopment .20:114.http:// www. 1rrd.org/lrrd 20/7/dadi20114.htm.

- Duncan, D.B. (1955): Multiple range and multiple Ftest. Biometrics, 11:1-42.. 
- El-Fouly, H.A.; Ashmawi, G.M.; El-Talty, Y. and Salama, O. (1984). Rahmani sheep: estrus and mating performance as affected by season of mating and type of feed. Egypt. J. Anim. Prod., 24: 111-117.

- Fatet, A.; Pellicer-Rubio M. T. and Leboeuf, B (2011). Reproductive cycle of goats. Anim. Reprod. Sci. 124: 211-219.

- Gabr, M.G.; Aboul-Naga, A.M.; Aboul-Ela, M.B. and El-NakhIa, S.M. (1989). Seasonal variation rate, litter size and ova wastage in local Rahmai and Ossimi ewes. Proceedings of $3^{\text {rd }}$ Egyptian-British Conference on Animal, Fish and Poultry Production, Alexandria, Egypt.

- Habeeb, A.A; El-Masry, K.A. and Atta, M.A.A. (2014). Growth traits of purebred and crossbred Bovine calves during winter and summer seasons. 4th Int. Con. Rad. Res. Appl. Sci., Taba, Egypt. 1:10.

- Habeeb, A. A. M; Gad, A. E. and El-Tarabany, A. A. (2011). Effect of hot climatic conditions with different types of housing on productive efficiency and physiological changes in Buffalo calves. Zagaz. Vet. J., 39 (3): 34-48.

- Hansen, J. P. (2009): Effects of heat stress on mammalian reproduction. Phil.Trans.R. Soc. B., 364: 33413350 .

- Hennessy, D. P.; Coghlan, J. P.; Hardy, K. J.; Scoggins, B.A. and Wintour, E.M. (1982). The origin of cortisol in the blood of fetal sheep. J. Endo., (95): 7179.

- Hermiz, H.N.; Al-Amily, H.J. and Assak, E.A. (1997). Some genetic and non-genetic parameters for pre-weaning growth traits in Angora goats. Dirasat. Agric. Sci. 24: 182-188.

- Husain, S.S.; Horst, P. and Islam, A.B.M.M. (1996). Study on the growth performance of Black Bengal goats in different periods. Small Rumin. Res. 21: 165171.

- Jordan, E. R. (2003): Effects of heat stress on reproduction. J. Dairy Sci. 86: E. Suppl.: E104-E114.

- Kamal, T.H. and Johnson, H. D. (1971). Total body solids as a measurement of a short-term heat stress in cattle. J. Anim. Sci., 32: 306-311.

- $\quad$ Kinne, M. (2000). One + one shouldnet $=$ One in Pigmy Goats. http://kinne.net/1plusl.htm

- Kumar, R.; Jindal, R. and Rattan, P. J. S. (1991). Plasma hormonal profiles during oestrous cycle of Murrah buffalo heifers. Ind. J. Anim. Sci. 61:382-385.

- Madan, M. L.; Prakash, B. S.; Jailkhani, S.; Singla, S. K.; Palta, P.and Manik, R. S. (1993). In: Buffalo endocrinology with special reference to embryo transfer. Embryo Biotechnology Centre, NDRI, Karnal, India, pp. 32.

- Madibela, O.R.; Mosimanyana, B.M.; Boitumelo, W.S. and Pelaelo, T.D .(2002). Effect of supplementation on reproduction of wet season kidding Tswana goats. South African J. Animal Sci., 32:14-22.

- Marai, I.F.M., Bahgat, L.B., Shalaby, T.H. and Abdel-Hafez, M.A. (2000). Fattening performance, some behavioural traits and physiological reactions of male lambs fed concentrates mixture alone with or without natural clay, under hot summer of Egypt. Ann. Arid Zone, 39 (4): 449-460.

- Marai, I.F.M.; El-Darawany, A.A.; Abou-Fandoud, E.I. and Abdel-Hafez, M.A.M. (2004). Reproductive traits and the physiological background of the seasonal variations in Egyptian Suffolk ewes under the conditions of Egypt. Annals of Arid Zone, 42: 1-9.

- Marai, I.F.M.; El- Darawany, A.A.; Abou-Fandoud, E.I. and Abdel-Hafez, M.A.M.(2006). Serum blood components during pre-estrus, estrus and pregnancy phases in Egyptian Suffolk as affected by heat stress, under the conditions of Egypt. Egypt. J. Sheep, Goats and Desert Anim. Sci., 1: 47-62.

- Marai, I.F.M. and Habeeb, A.A.M. (1998). Adaptability of Bos Taurus cattle under hot arid conditions. J. Arid Zone, 37 (3): 253-281.

- Marai, I.F.M. and Habeeb, A.A.M. (2010). Buffalo's biological functions as affected by heat stress. J. Livestock Sci., 127: 89-109.

- Marai, I.F.M.; Habeeb, A.A.M. and Gad, A.E., 
(2002). Reproductive traits of female rabbits as affected by heat stress and light regime, under sub-tropical conditions of Egypt. J. Anim. Sci. 75: 451-458.

- Mellado, M. and Meza-Herrera, C. A. (2002). Influence of season and environment on fertility of goats in a hot-arid environment. J. Agric. Sci. 138 Issue 01: 97-102.

- Mia, M.M.; Khandoker, M.A.M.Y. ; Husain, S.S.; Faruque, M.O. ; Notter, D.R. and Haque, M.N. (2013). Genetic evaluation of growth traits of black bengal goat. Irania. J. Appli. Anim. Sci. 3 (4): 845-852.

- Mokhtar, M.M.; Abdel-Bary, H.T. and El-Sharabasi, A.M. (1991). Seasonal variation in the fertility of crossbred ewes. Egypt. J. Anim. Prod., 28: 31-38.

- Mormède, P.; Foury , A.; Terenina, E. and Knap, P.W., (2011). Breeding for robustness: the role of cortisol. Animal. 5:651-7.

- $\quad$ Nazifi, S.; Saeb, M.; Rowghani, E. and Kaveh, K. (2003) The influences of thermal stress on serum biochemical parameters of Iranian fat-tailed sheep and their correlation with Triidothyronine (T3), Thyroxine (T4) and cortisol concentrations. Comp. Clin. Pathol., 12(3): 135-139.

- Ninan, J. and Vadodaria, V.P. (2000). Serum cortisol, triiodothyronine and thyroxine levels at periparturient periods in Patanwadi ewes .Indan Vet. J. (77): 10401042.

- NRC. (2007). Nutrient requirements of small ruminants: Sheep, Goats, Cervids, and New World Camelids. Natl. Acad. Press, Washington, DC.

- Olson,T.A. (2011). Crossbreeding programs for beef cattle in Florida publication. University of Florida, IFAS Extension, BUL, 326.

- $\quad$ SAS (1991). Statistical Analysis System, SAS User's Guide Statistics, SAS Institute Inc., Editions Cary NC.

- Schoeman, S.J. (2000). A comparative assessment of Dorper sheep in different production environments and systems. Small Rum. Res. 36: 137 - 146.

- $\quad$ Singh D.K. (1997). Genetic studies on post-weaning body weights of Black Bengal and its half-breeds with
Jamunapari and Bee-tal goats. Indian J. Anim. Sci. 67: 1015-1017.

- $\quad$ Singh, D.K.; Singh, C.S.P. and Mishra, H.R. (1991). Factors affecting growth of Black Bengal and its crossbred with Jamunapari and Beetal goats. Indian J. Anim. Sci., 61: 1101-1105.

- Singh, N.K. and Singh, D.K. (1998). Growth rate of Black Bengal and its crosses with Beetal under village conditions. Indian J. Anim. Sci. 68: 988-990.

- Steine, T.A. (1975). Faktorar med innverknad pa oekonomisk viktige eigenskapar hos geit (Factors affecting characters of economic importance in goats). Meldinger fra Norges Landbrukshoegskole. 54 (2): 30

- Suganaya, G. and Gomathy, V.S. (2009). Hormone profile of Tellicherry goats during per parturient period. Tamilnadu J. Vet. Anim. Sci., 5 (5): 211-213.

- Taiwo, B.B.A.; Buvanendran, V. and Adu, I.F. (2005). Effects of body condition on the reproductive performance of Red Sokoto goats. Nig. J. Anim. Prod. 32(1): 1-6.

- Warmington, B.G. and Kirton, A.H. (1990). Genetic and non-genetic influences of growth and carcass traits of goats. Small Rumin. Res. 3: 147-165.

- Wise, M.E.; Armstrong, D.V.; Huber, J.T.; Hunter, R. and Wiersma, F. (1988). Hormonal alterations in the lactating dairy cow in response to thermal stress. J. Dairy Sci. 71: 2480-2485.

- Zahradden, D.; Butswat, I.S.R. and Mbap, S.T. (2008). Evaluation of some factors influencing growth performance of local goats in Nigeria. Afr. J. Food, Agric., Nutr. Dev. 8 (4): 464 - 479.

- Zhengkang, H.; Zhenzhong, C.; Shaohua, Z.; Vale, W.G.; Barnabe, V.H. and Mattos, J.C.A., (1994). Rumen metabolism, blood cortisol and T3, T4 levels and other physiological parameters of swamp buffalo subjected to solar radiation. Proas World Buffalo Cong., San. Paulo. Brazil 2: 39-40. 
مجدم

\section{التققنيــات النــــوويــــة فى العلوم التطبيقية}

متجلد 6، عدد 1 ، ص 31 : 45، (2018)

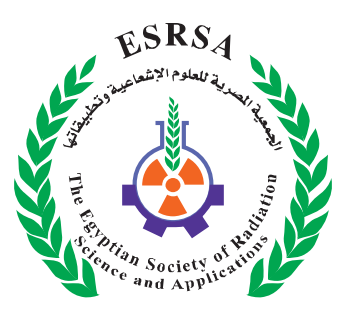

\section{تأثير الإجهاد الحراري على الصفات التناسليت والإنتاجيتّفى إناث الماعز البلدي والخليط تحت الظروف شبد الحاره}

عبدالكريم إبراهيم محمدد السيد' ، حسن أحمد مصطفى فرغلي"، شريف يوسف عيد بوحسين مصطفى الظاهر'

أجريت هذة التجر بت لدراست أثر الإجهاد الحرارى على الصفات التناسليت والانتاجيت في إناث الماعز

البلدي والخليط (50\% بلدى 10\% زرايبى) وذلك تحت ظروف كلا من المناخ الحار (فصل الصيف)

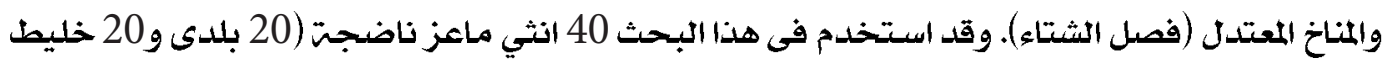

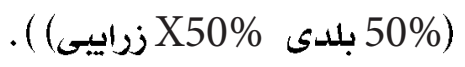

أوضحت النتائج زيادة غير معنويتَ فى كل معدل الخصوبت والحمل والولادة وغزارة الانتاج خلال الظروف المناخيت معتدلت الحراره مقارنت بالظروف المناخيت الحارة. سجلت جهيع الصفات التناسليت زيادة يج اناث الماعز الخليط مقارنت باناث الماعز البلدي. اظهرت إناث الماعز الخليط زيادة معنويت (> 0.01 or P > 0.0001 في جهيع الصفات الإنتاجيت مقارنت بإناث الماعز البلدي.

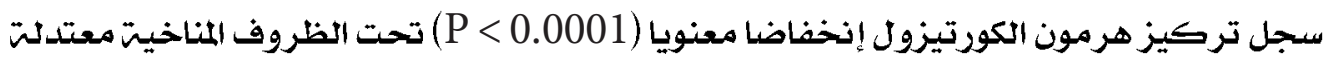
الحرارة مقارنت بالظروف المناخيت الحارة خلال مختلف مراحل دورة الثبق و الحمل ومابعد الولادة.

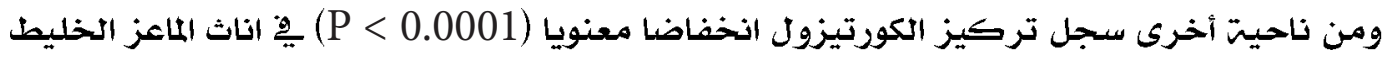
مقارنت بإناث الماعز البلدي خلال مختلف مراحل دورة الشبق ماعدا مرحلت اللاشبق. كان تأثير السلالت مِّف مختلف مراحل الحمل وفترة مابعد الولادة تأثيرا معنويا تتأثير السلادت خلال مختلف مراحل دورة الشبق. من نتائج هذه التجربت يهكن استخلاص ان لكل

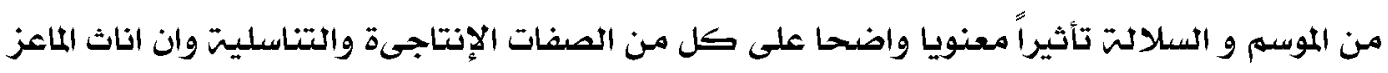
الخليط كانت افضل من البلدي. 
